damage to the tissues. The application of this form of therapy by an ophthalmoscope produces new technical problems, but when these are adequately solved it could lead to a wider use of phototherapy.

The history of laser development is reviewed very briefly. The laser ophthalmoscope designed in Newcastle upon Tyne is described. The present model is very similar, both in size and in weight, to a standard battery-operated ophthalmoscope. The ruby crystal is contained in the handle, which is connected to the power pack by a flexible lead.

Preliminary clinical experiments which were carried out on rabbits are described and the results are compared with those obtained in the limited number of human beings so far treated with the instrument.

The differences between laser lesions, diathermy lesions, and lesions produced by the Zeiss xenon arc coagulator are discussed.

The use of various lasers in industry are referred to briefly, and some effects of high doses on rabbits' eyes are shown to illustrate possible hazards which may be encountered as the use of lasers becomes more widespread.

The histology of therapeutic laser lesions is described and a brief reference is made to some lesions produced by excessive dosage.

We wish to acknowledge the help we have received from Professor A. G. Heppleston and his staff, of the department of pathology.
We also wish to record our gratitude to Dr. H. Rose, of the International Research and Development Company, Limited, for his enthusiastic collaboration, and to $\mathrm{Mr}$. W. Hetherington for all his help with the practical work of constructing the laser. We are also indebted to Thermal Syndicate Limited, Wallsend on Tyne, for supplying the laser crystals, and to Messrs. Keeler Limited, of London, for their collaboration in producing the ophthalmosocope.

The cost of the research was borne by the International Research and Development Company, Limited, and the United Newcastle upon Tyne Hospitals.

\section{BIBLIOGRAPHY}

Alsop, L. E., Giordmaine, J. A., Townes, C. H., and Wang, T. C. (1957). Phys. Re.v., 107, 1450 .

Basov, N. G., and Prokhorov, A. M. (1954). f. exp. theor. Phys. (U.S.S.R.), $27,431$.

Bloembergen, N. (1956). Phys. Rev., 104, 324

Collins, R. J., Nelson, D. F., Schawlaw, A. L., Bond, W., Garrett, C. G. B., and Kaiser, W. (1960). Phys. Rev. Lett., 5, 303.

Combrisson, J., Honig, A., and Townes, C. H. (1956). 'C.R. Acad. Sci. (Paris), 242, 2451; Onde élect., 36, 989.

Einstein, A. (1917). Zur quantentheorie der Strahlung.

Gordon, J. P., Zeiger, H. Z., and Townes, C. H. (1954). Phys. Rev., $95,282$.

- (1955). Ibid., 99, 1264.

Ingram, H. V. (1964). Trans. ophthal. Soc. U.K. In press.

Maiman, T. H. (1960a). Nature (Lond.), 187, 493.

- (1960b). Brit. Commun. Electron., 7, 674.

Meyer-Schwickerath, G. (1960). Light Coagulation, p. 49. Kimpton,

Scovil, H. E. D., Feher, G., and Seidel, H. (1957). Phys. Rev., 105, 762.

Weber, J. (1953). Trans. I.R.E., Prof. Group on Electron Devices. PGED-3 (June, 1953).

\title{
Small-intestinal and Gastric Abnormalities in Ulcerative Colitis
}

\author{
S. N. SALEM,*† M.B., CH.B., M.R.C.P.ED. ; S. C. TRUELOVE,* M.D., F.R.C.P.
}

Brit. med. F., 1965, 1, 827-831

In a previous article (Salem et al., 1964) we reported the results of a pilot study of the state of the small intestine and stomach in ulcerative colitis. It was found that during an actual attack of ulcerative colitis the small-intestinal mucosa frequently showed villous abnormalities in biopsy specimens and the faecal fat excretion was often abnormally high ; and, correspondingly, the stomach often showed superficial gastritis. Among the patients studied in remission the stomach and.small intestine were usually normal as judged by these same criteria.

Since then the study has been considerably enlarged. First, a bigger group of patients with ulcerative colitis has been studied, so that some of our tentative conclusions of the pilot study can be re-examined with the aid of more extensive data. Secondly, some of the patients have been reinvestigated to see if any abnormalities in their small intestine and stomach fluctuate in unison with changes in the severity of their ulcerative colitis. Thirdly, because some of the villous abnormalities of the small intestine were comparatively minor, various control subjects have been examined to provide a yardstick of normality - a necessary step in view of the limited biopsy observations which have been made upon the healthy human small intestine.

\section{Methods}

Small-intestinal Biopsy.-We have continued to use a Crosby capsule, but one modified by the fitting of a latex sheath to avoid the occasional loss of the dome of the capsule and by the use of radio-opaque tubing to facilitate radiological localization.

* Nuffield Department of Clinical Medicine, University of Oxford. + Physician in the Kuwait Government Medical Service on study leave.
These modifications are described in detail elsewhere (Salem et al., 1965). The biopsy specimen was fixed and stained as in the pilot study.

Gastric Biopsy.-This also was performed by means of the Crosby capsule.

Faecal Fat.-As in the pilot study, the faecal fat excretion has been based on a four-day collection of stools with the patient on a standard hospital diet (or on his ordinary diet if an outpatient), using the method of van der Kamer et al. (1949) to estimate total lipids. A daily faecal excretion of $6 \mathrm{~g}$. or more of total fat has been taken as abnormal.

Vitamin- $B_{12}$ Absorption.-No further observations have been made since the pilot study, when it was found that most patients with ulcerative colitis showed normal absorption.

D-Xylose Excretion Test.-In this pilot study it was found that the standard test employing $25 \mathrm{~g}$. of $\mathrm{D}$-xylose gave rise to abdominal pain and increased diarrhoea in patients with ulcerative colitis, so that the test was unsuitable in that form. The modified test of Santini et al. (1961), which employs $5 \mathrm{~g}$. of $\mathrm{D}$-xylose, has proved to be suitable for use in ulcerative colitis and has been utilized. Santini et al. (1961) have provided evidence of the reliability of this test with the smaller dose, a finding confirmed by others (Sammons et al., 1962).

Electron Microscopy.-Some of the small-intestinal biopsy specimens have been examined under the electron microscope by Dr. J. C. F. Poole, of the Sir William Dunn School of Pathology, Oxford University. For this purpose the biopsy specimen was immediately cut into two halves on recovery from the capsule. One half was immediately impregnated with osmium tetroxide and divided into small portions for fixation 
in Caulfield medium, followed by embedding in araldite (Palade, 1952 ; Caulfield, 1957). The other half was used for dissectingmicroscope studies and ordinary light microscopy.

Histochemistry.-A small number of small-intestinal specimens have been studied histochemically for a variety of enzymes, as mentioned in the body of the text. The biopsy specimen was immediately cut into halves on recovery from the capsule. One half was immediately quick-frozen and prepared for cutting by Cryostat to yield sections for histochemical examination. The other half was used for dissectingmicroscope and ordinary histological studies.

\section{Patients Studied}

Sixty patients with ulcerative colitis have been studied. Some were in a frank attack of the disease at the time of study, but others were in a stage of remission. Some patients were receiving corticosteroid therapy, but others were on no specific form of treatment. Ten of these patients have been reinvestigated after a period of time varying from 2 to 14 months from the initial investigation. In every case small-intestinal biopsy was performed, but the full range of other tests was not always feasible.

It was not thought justifiable to study healthy subjects as controls for the small-intestinal and gastric biopsy studies, but three groups of patients have been used-namely, (a) 27 patients with a functional disturbance of the large bowel of the type known as irritable-colon syndrome and meeting the diagnostic requirements described elsewhere (Chaudhary and Truelove, 1962); (b) 14 patients with severe psoriasis picked out for treatment with folic-acid antagonists by our dermatological colleagues (Ryan et al., 1964); (c) 14 patients with anaemia, either pernicious anaemia or simple iron-deficiency anaemia. (Subjects in this group have been used as controls only for small-intestinal findings, because it is well known that atrophic gastritis or gastric mucosal atrophy is universal in pernicious anaemia, while varying degrees of gastritis are common in iron-deficiency anaemia, as either cause or effect.)

\section{Small-intestinal Biopsy Findings}

As in the pilot study, the appearances of the small-intestinal specimens have been classified into four categories:

Category I. Normal.-Under the dissecting microscope the great majority of the villi are slender finger-like protuberances, although a few tongue-shaped or small leafshaped villi may be present. Histologically, virtually all the villi are slender and normal.

Category II. Minor Villous Abnormalities.-In addition to the finger-like villi, numerous leaf-shaped villi are visible under the dissecting microscope, and occasional branched and convoluted villi may also be present. Histologically, elongated villous ridges extending more than $1,000 \mu$ are present in tangential sections among the relatively normal villi.

Category III. Marked Villous Abnormalities (Partial Villous Atrophy). - The mucosal surface consists of ridges and convolutions, with only a few leaf-shaped or tongueshaped villi among them.

Category IV. Subtotal Villous Atrophy.-The mucosal surface is flat and devoid of villi.

The histological investigations on the biopsy specimens were carried out by the pathologist, who did not know the clinical state of the patient.

Small-intestinal Biopsy Findings in Ulcerative Colitis and Control Subjects.-Table I shows a striking difference between the biopsy specimens obtained from patients with ulcerative colitis and those obtained from control subjects. Among the 55 control subjects there were only three whose small-intestinal specimen showed any abnormality, and even then the abnormality was minor. It is especially noticeable that the 27 patients with irritable-colon syndrome included in the control group all yielded entirely normal biopsy specimens. By contrast, more than two-thirds of the specimens obtained from patients with ulcerative colitis were abnormal, and the abnormalities were pronounced in about one-quarter of the specimens.

TABLE I.-Comparison of the Small-intestinal Biopsy Specimens Obtained from 60 Patients with Ulcerative Colitis and Those Obtained from 55 Control Subjects

\begin{tabular}{|c|c|c|c|c|c|c|}
\hline \multirow{2}{*}{\multicolumn{2}{|c|}{ Clinical Category }} & \multicolumn{4}{|c|}{ Small-intestinal Mucosa Category } & \multirow{2}{*}{ Totals } \\
\hline & & I & II & III & IV & \\
\hline $\begin{array}{l}\text { Irritable colon } \\
\text { Psoriasis } \quad \ldots \\
\text { Anaemia }\end{array}$ & $\begin{array}{l}\cdots \\
\cdots \\
\cdots\end{array}$ & $\begin{array}{l}27 \\
13 \\
12\end{array}$ & $\begin{array}{l}1 \\
2\end{array}$ & & & $\begin{array}{l}27 \\
14 \\
14\end{array}$ \\
\hline $\begin{array}{l}\text { Total controls } \\
\text { Ulcerative colitis }\end{array}$ & $\begin{array}{l}\cdots \\
\therefore\end{array}$ & $\begin{array}{l}52 \\
19\end{array}$ & $\begin{array}{r}3 \\
27\end{array}$ & 12 & 2 & $\begin{array}{l}55 \\
60\end{array}$ \\
\hline
\end{tabular}

Relation of Small-intestinal Abnormalities to Clinical State.Table II shows the correlation between the clinical state of the patient with ulcerative colitis and the findings on smallintestinal biopsy. It can be seen that there is a progressive increase in the proportion of patients showing small-intestinal abnormalities as the disease becomes more severe clinically. Marked mucosal abnormalities are confined to those patients with moderate or severe ulcerative colitis. Only two patients (both with severe ulcerative colitis) showed complete loss of villi with the picture of subtotal villous atrophy. The first of these had severe liver disease as a complication of his ulcerative colitis, but in the second the liver was normal, both clinically and biochemically, so it appears that the ulcerative colitis and not the liver disease is the relevant association; and this is borne out by our finding that four other patients in the series with subacute or chronic hepatitis complicating their ulcerative colitis do not show subtotal villous atrophy.

Length of History and Age of Patient.-The length of history of the ulcerative colitis does not have a major bearing upon the small-intestinal abnormalities observed on biopsy, as can be seen from Table III. In other words, there is no indication that the small-intestinal abnormalities are a special consequence of chronic disease as they are prominent in patients with a short history. Likewise, the age of the patient has no major bearing on the liability of the small-intestinal mucosa to be abnormal (Table IV).

TABLE II.-Relation Between Clinical Activity of Ulcerative Colitis and State of Small-intestinal Mucosa as fudged from Biopsy Specimens in 60 Patients

\begin{tabular}{|c|c|c|c|c|c|}
\hline \multirow{2}{*}{$\begin{array}{c}\text { Clinical State } \\
\text { as Regards } \\
\text { Ulcerative Colitis }\end{array}$} & \multicolumn{4}{|c|}{ Small-intestinal Mucosa Category } & \multirow{2}{*}{ Total } \\
\hline & I & II & III & IV & \\
\hline $\begin{array}{l}\text { Symptom-free } \\
\text { Mild .. } \quad \ldots \\
\text { Moderate } \quad \ldots \\
\text { Severe }\end{array}$ & $\begin{array}{l}8 \\
6 \\
4 \\
1\end{array}$ & $\begin{array}{r}4 \\
10 \\
10 \\
3\end{array}$ & $\begin{array}{l}6 \\
6\end{array}$ & 2 & $\begin{array}{l}12 \\
16 \\
20 \\
12\end{array}$ \\
\hline
\end{tabular}

TABLE III.-Relation Between Length of History of Ulcerative Colitis

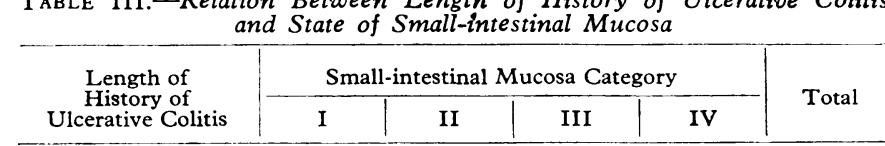

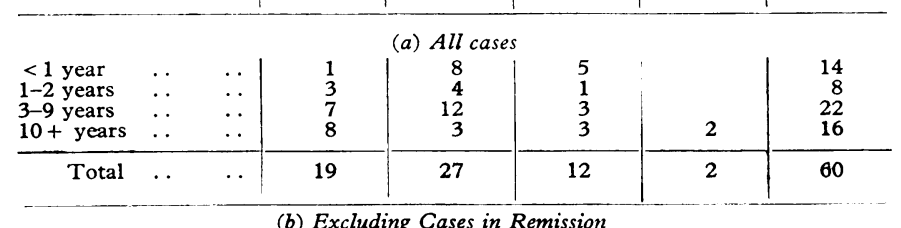

\begin{tabular}{rll|r|r|r|r|r} 
(b) Excluding Cases in Remission & & \\
$<1$ year & $\ldots$ & $\ldots$ & & 7 & 5 & & 12 \\
$1-2$ years & $\ldots$ & $\ldots$ & 3 & 3 & 1 & & 7 \\
3-9 years & $\ldots$ & $\ldots$ & 6 & 11 & 3 & & 20 \\
$10+$ years &. & $\ldots$ & 2 & 2 & 3 & 2 & 9 \\
\hline Total & $\ldots$ & $\ldots$ & 11 & 23 & 12 & 2 & 48 \\
\hline
\end{tabular}


TABLE IV.-Lack of any Relation Between Age of Patient with Ulcerative Colitis and State of Small-intestinal Mucosa in 60 Patients (Including 12 Who Were Symptom-free)

\begin{tabular}{|c|c|c|c|c|c|c|}
\hline \multirow{2}{*}{\multicolumn{2}{|c|}{ Age-group }} & \multicolumn{4}{|c|}{ Small-intestinal Mucosa Category } & \multirow{2}{*}{ Total } \\
\hline & & I & II & III & IV & \\
\hline $\begin{array}{l}<30 \text { years } \\
30-49 \text { years } \\
50+\text { years }\end{array}$ & $\begin{array}{l}\cdots \\
\cdots\end{array}$ & $\begin{array}{l}3 \\
7 \\
9\end{array}$ & $\begin{array}{r}11 \\
12 \\
4\end{array}$ & $\begin{array}{l}4 \\
6 \\
2\end{array}$ & $\begin{array}{l}1 \\
1\end{array}$ & $\begin{array}{l}18 \\
26 \\
16\end{array}$ \\
\hline
\end{tabular}

Faecal Fat Excretion.-The faecal fat excretion was abnormally high in 18 of the 54 patients in whom it was studied. The faecal fat excretion is strongly correlated with the clinical activity of the ulcerative colitis (Table V). Similarly, there is a close association between the state of the smallintestinal mucosa as judged from the biopsy specimen and the faecal fat excretion (Table VI).

TABLE V.-Relation Between Clinical State and Faecal Fat Excretion

\begin{tabular}{|c|c|c|c|c|}
\hline \multicolumn{3}{|c|}{$\begin{array}{l}\text { Clinical State of } \\
\text { Ulcerative Colitis }\end{array}$} & No. of Patients & $\begin{array}{l}\text { No. With Abnormal } \\
\text { Faecal Fat Excretion }\end{array}$ \\
\hline $\begin{array}{l}\text { Symptom-free } \\
\text { Mild attack } \\
\text { Moderate attack } \\
\text { Severe attack }\end{array}$ & $\begin{array}{l}\cdots \\
\cdots \\
\cdots\end{array}$ & $\begin{array}{l}\cdots \\
\cdots \\
\cdots\end{array}$ & $\begin{array}{l}12 \\
13 \\
19 \\
10\end{array}$ & $\begin{array}{r}0 \\
3 \\
5 \\
10\end{array}$ \\
\hline Total & $\ldots$ & $\ldots$ & 54 & 18 \\
\hline
\end{tabular}

TABLE VI.-Relation Between State of Small-intestinal Mucosa, as fudged by Biopsy Specimen, and Faecal Fat Excretion

\begin{tabular}{c|c|c}
\multicolumn{2}{c}{$\begin{array}{c}\text { Small-intestinal } \\
\text { Mucosa Category }\end{array}$} & Faecal Fat Excretion \\
\cline { 2 - 3 } & No. of Patients & $\begin{array}{c}\text { No. with Abnormally } \\
\text { High Faecal Fat }\end{array}$ \\
\hline I & 17 & 1 \\
II & 25 & 8 \\
III & 10 & 7 \\
IV & 2 & 2
\end{tabular}

D-Xylose Absorption-excretion Test.-Of the 30 patients studied with the modified D-xylose test of Santini et al. (1961) seven showed abnormal results. As with the faecal fat excretion, there is a pronounced correlation with the clinical state (Table VII), no abnormal results occurring in the six patients studied during remission, but increasing proportions of

TABLE VII.-Relation Between Clinical State and D-Xylose Excretion Test

\begin{tabular}{|c|c|c|c|c|}
\hline \multicolumn{3}{|c|}{$\begin{array}{l}\text { Clinical State of } \\
\text { Ulcerative Colitis }\end{array}$} & No. of Patients & $\begin{array}{c}\text { Abnormal } \\
\text { D-Xylose Test }\end{array}$ \\
\hline 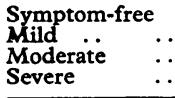 & $\begin{array}{l}\cdots \\
\cdots \\
\cdots\end{array}$ & $\begin{array}{l}\cdots \\
\cdots \\
\cdots\end{array}$ & $\begin{array}{r}6 \\
8 \\
12 \\
4\end{array}$ & $\begin{array}{l}0 \\
1 \\
3 \\
3\end{array}$ \\
\hline Total .. & . & . & 30 & 7 \\
\hline
\end{tabular}

abnormal results as the attack of ulcerative colitis becomes more severe. Likewise, there is a strong association between the small-intestinal biopsy findings and the results of the D-xylose test (Table VIII), with abnormal results occurring only in those patients with an abnormal mucosa.

TABLE VIII.-Relation Between State of Small-intestinal Mucosa, as Fudged by Biopsy Specimen, and D-Xylose Excretion Test

\begin{tabular}{c|c|c}
\hline $\begin{array}{c}\text { Small-intestinal } \\
\text { Mucosa Category }\end{array}$ & No. of Patients & $\begin{array}{c}\text { No. with Abnormal } \\
\text { D-Xylose Test }\end{array}$ \\
\hline I & 8 & 0 \\
II & 15 & 3 \\
III & 6 & 3 \\
IV & 1 & 1 \\
\hline
\end{tabular}

The faecal fat excretion and the D-xylose test do not necessarily correlate, because they do not measure identical functions. The faecal fat excretion may be abnormal either because the digestion of fat is faulty (as in pancreatic deficiency or in obstructive jaundice), or because the small intestine does not absorb normally. The D-xylose test is simply a measure of small-intestinal absorption, provided that renal function is normal. It is therefore useful to see how well the two tests correlate in the present series of ulcerative colitis patients. Table IX shows an almost perfect agreement between these two tests, which we believe must indicate that the main defect in ulcerative colitis is faulty absorption from the small intestine rather than depressed digestive power.

TABLE IX.-Relation Between Faecal Fat Excretion and D-Xylose Test

\begin{tabular}{lll|c|c|c}
\hline \multicolumn{2}{c|}{ Faecal Fat Excretion } & & No. of Patients & $\begin{array}{c}\text { No. with Abnormal } \\
\text { D-Xylose Test }\end{array}$ \\
\hline Normal & $\ldots$ & $\ldots$ & $\ldots$ & 22 & 1 \\
Abnormal & $\cdots$ & $\cdots$ & $\cdots$ & 8 & 6 \\
\hline
\end{tabular}

Corticosteroid Therapy.-This has no bearing on the changes found in small-intestinal biopsy (Table X).

TABLE X.-Lack of Relation Between Corticosteroid Therapy and State of Small-intestinal Mucosa in Patients in an Attack of Ulcerative Colitis. (Twelve Patients Who Were Symptom-free Have Been Excluded)

\begin{tabular}{c|c|c|c|c|c}
\hline \multirow{2}{*}{$\begin{array}{c}\text { Corticosteroid } \\
\text { Therapy }\end{array}$} & \multicolumn{4}{|c|}{ Small-intestinal Mucosa Category } & \multirow{2}{*}{ Total } \\
\cline { 2 - 6 } & I & II & III & IV & \\
\hline+ & 7 & 15 & 7 & 2 & 31 \\
\hline & 4 & 8 & 5 & & 17 \\
\hline
\end{tabular}

Histochemical Abnormalities.-The intestinal biopsy specimens of five patients with ulcerative colitis have been examined for alkaline phosphatase, acid phosphatase, esterase, cytochrome oxidase, monoamine oxidase, 5-nucleotidase, and adenosine triphosphatase (A.T.P.-ase). The findings have been compared with those obtained from a patient with the irritablecolon syndrome, which we regard as a normal control for the present purpose, and also with those obtained from two patients with idiopathic steatorrhoea in which depression of enzyme activity in the small-intestinal mucosa is known to be pronounced (Padykula et al., 1961). In three of the five patients with ulcerative colitis there was a reduction of acid phosphatase -in one case only to a moderate degree, but in the other two in quite a pronounced degree, although not to the same extent as in idiopathic steatorrhoea. So far as 5-nucleotidase is concerned, this was absent in one of the ulcerative colitis specimens as well as in both of those with idiopathic steatorrhoea. Some depression of other enzymes was observed in some of the ulcerative colitis specimens. This small number of observations does not permit of definite conclusions about the extent to which enzyme activity is depressed in the small-intestinal mucosa in ulcerative colitis, but the results suggest that the whole issue deserves to be studied in detail.

Electron Microscopy. - The small-intestinal biopsy specimens of patients with ulcerative colitis and of control patients have been examined by electron microscopy. The small-intestinal epithelial cells in ulcerative colitis appear to be entirely normal, with well-formed microvilli, even in those patients with partial villous atrophy. The results will be reported in detail elsewhere (Poole and Salem, 1965).

Gastric Biopsy Findings.-Gastric biopsy has been successfully carried out in 55 of the 60 patients with ulcerative colitis. Superficial gastritis is fairly common in patients with active ulcerative colitis but was not found in any of the 12 patients

TABLE XI.-Relation Between Clinical Activity of Ulcerative Colitis and State of Gastric Mucosa as fudged from Biopsy Specimen

\begin{tabular}{|c|c|c|c|c|c|}
\hline \multicolumn{4}{|l|}{ Stale } & \multicolumn{2}{|r|}{ 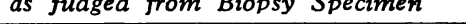 } \\
\hline \multicolumn{4}{|c|}{$\begin{array}{l}\text { Clinical State of } \\
\text { Ulcerative Colitis }\end{array}$} & No. of Patients & $\frac{\text { No. with }}{\text { Superficial Gastritis }}$ \\
\hline $\begin{array}{l}\text { Remission } \\
\text { Mild .. } \\
\text { Moderate } \\
\text { Severe }\end{array}$ & $\begin{array}{l}\ldots \\
\cdots \\
\cdots\end{array}$ & $\begin{array}{l}\ldots \\
\because \\
\cdots\end{array}$ & $\begin{array}{l}\cdots \\
\cdots \\
\cdots\end{array}$ & $\begin{array}{l}12 \\
15 \\
18 \\
10\end{array}$ & $\begin{array}{l}0 \\
5 \\
2 \\
3\end{array}$ \\
\hline & & & & 55 & 10 \\
\hline
\end{tabular}


examined while in complete remission, suggesting that the gastritis is usually a temporary and reversible disturbance (Table XI). It is worth noting that evidence of gastric mucosal atrophy was virtually absent. It is also interesting that the proportion of patients with superficial gastritis does not appear to reflect the severity of the ulcerative colitis, which is in contrast to what is found with the small intestine. In brief, the gastric mucosal changes appear to be relatively slight compared with those shown by the small-intestinal mucosa.

Vitamin- $B_{12}$ Absorption.-No further observations have been made since our pilot study, which included 19 patients with ulcerative colitis in whom the absorption of vitamin $B_{12}$ had been measured. In the great majority absorption was normal.

\section{Repeat Observations}

Ten of the 60 patients with ulcerative colitis have been re-examined after a lapse of time varying from 2 to 14 months from the original observations. It is therefore possible to see whether the small-intestinal abnormalities fluctuate in unison with the changing activity of the ulcerative colitis.

Table XII summarizes the findings in these 10 patients. It can be seen that there are changes in the small-intestinal mucosa which almost always run in parallel with any change in the clinical activity of the ulcerative colitis, and the tests of smallintestinal function (when done) also usually move in parallel. By contrast, the gastric mucosa seems to show much less change.

The results indicate that the small-intestinal mucosa is in a highly plastic condition in ulcerative colitis. Patients with partial villous atrophy during a severe attack of ulcerative colitis possess either completely normal or only mildly abnormal smallintestinal mucosa when subsequently examined in a complete clinical remission of the disease. Conversely, patients originally examined when the ulcerative colitis is quiescent or mild possess normal or only mildly abnormal villous structure of the small intestine but are likely to show more pronounced villous abnormalities when examined subsequently during a sharp attack of ulcerative colitis.

\section{Discussion}

The present study has confirmed and extended the conclusions which we drew in our pilot study. The small intestine has often been found to be abnormal during an active stage of ulcerative colitis. Biopsy shows a progressive increase in the proportion of patients with villous abnormalities as the attack of ulcerative colitis becomes more severe. Small-intestinal function is also disturbed, both the faecal fat levels and the $\mathrm{D}$-xylose test frequently being abnormal. These two tests of small-intestinal function usually correspond in ulcerative colitis and they are both closely correlated with the degree of villous abnormality found in the biopsy specimen. It is interesting that biopsy specimens showing partial villous atrophy do not possess abnormal epithelial cells on electron microscopy, but this same lack of relationship has been shown in idiopathic steatorrhoea (Shiner and Birbeck, 1961 ; Shearman et al., 1962). In effect, the low-power view obtained with the dissecting microscope appears to be a better guide to function than the electron-microscope appearances.

The question of why there should be impaired small-intestinal function in our patients with villous abnormalities remains unsettled. Such villous abnormalities must reduce the surface area of the small intestine, possibly to one-half or one-third of the normal, but as the microvilli are retained and appear entirely normal there is no reason to envisage any greater reduction in the absorbing area. In view of the enormous functional reserve of the healthy small intestine, an appreciable reduction of smallintestinal function as measured by the daily faecal fat excretion and the D-xylose test would hardly be expected. Two other possibilities at least are worth consideration. One is that the small intestine may become deficient in certain enzymes during an attack of ulcerative colitis. From our limited observations this appears to be a distinct possibility, but further work will be necessary to clinch it. The second is that the motor activity of the small intestine may become abnormal ; if so, absorption might be affected, because it has been shown that the hypomotility induced by propantheline can markedly reduce the absorption of sodium by human small intestine (Groisser and Farrar, 1962). We have made observations on several patients by intraluminal-pressure recording supplemented in some instances by simultaneous cineradiography, and it seems that the motility of the small intestine may be disturbed in ulcerative colitis; but once again further research is required for a definite answer.

We are still uncertain whether the small-intestinal abnormalities in ulcerative colitis are secondary to the disease in the colon or whether ulcerative colitis is in reality a disease which affects the entire intestine, although the brunt falls on the colon. We have seen one patient (Case 3 of Table XII) in whom the results of investigation are of great interest. He was a man aged 22 with ulcerative colitis complicated by extensive pseudopolyposis of the entire colon apart from the rectum and caecum. $\mathrm{He}$ showed partial villous atrophy and a faecal fat excretion of 18.8 g./day. He was treated by subtotal colectomy with caecoproctostomy (by Mr. C. U. Webster) with excellent symptomatic results. Three weeks after the operation the daily faecal fat was $7.6 \mathrm{~g}$. Five months after the operation he was fully re-examined, and the small-intestinal biopsy showed great improvement (although it was still not entirely normal), while the daily faecal fat had reached the borderline of normality $(6 \mathrm{~g}$.$) . It seems from this patient that removal of the colon has$ improved small-intestinal structure and function, which is in favour of the small-intestinal changes being secondary to the

TABLE XII.-Results of Re-examining a Sample of the Ulcerative Colitis Patients After a Lapse of Time

\begin{tabular}{|c|c|c|c|c|c|c|c|c|c|c|c|}
\hline \multirow[b]{2}{*}{ Case No. } & \multicolumn{5}{|c|}{ First Examination } & \multirow{2}{*}{$\begin{array}{l}\text { Time } \\
\text { Between } \\
\text { First } \\
\text { and } \\
\text { Second } \\
\text { Examina- } \\
\text { tions }\end{array}$} & \multicolumn{5}{|c|}{ Second Examination } \\
\hline & $\begin{array}{l}\text { Clinical } \\
\text { Activity } \\
\text { of } \\
\text { Ulcerative } \\
\text { Colitis }\end{array}$ & $\begin{array}{c}\text { Small- } \\
\text { Intestinal } \\
\text { Mucosa } \\
\text { Category }\end{array}$ & $\begin{array}{c}\text { Faecal } \\
\text { Fat }\end{array}$ & $\begin{array}{c}\text { D-Xylose } \\
\text { Test }\end{array}$ & $\begin{array}{l}\text { Gastric } \\
\text { Biopsy }\end{array}$ & & $\begin{array}{l}\text { Clinical } \\
\text { Activity } \\
\text { of } \\
\text { Ulcerative } \\
\text { Colitis }\end{array}$ & $\begin{array}{l}\text { Small- } \\
\text { Intestinal } \\
\text { Mucosa } \\
\text { Category }\end{array}$ & $\begin{array}{c}\text { Faecal } \\
\text { Fat }\end{array}$ & $\begin{array}{c}\text { D-Xylose } \\
\text { Test }\end{array}$ & $\begin{array}{l}\text { Gastric } \\
\text { Biopsy }\end{array}$ \\
\hline \multicolumn{12}{|c|}{ Cases Re-examined While in Remission } \\
\hline $\begin{array}{l}1 \\
2 \\
3 \\
4 \\
5 \\
6 \\
7\end{array}$ & $\begin{array}{l}\text { Severe } \\
\text { Moderate } \\
\text { Severe } \\
\text { Moderate } \\
\text { Severe }\end{array}$ & $\begin{array}{l}\text { III } \\
\text { III } \\
\text { III } \\
\text { III } \\
\text { III } \\
\text { III } \\
\text { II }\end{array}$ & $\begin{array}{r}16.3 \mathrm{~g} . \\
3.1 \mathrm{~g} . \\
18.8 \mathrm{~g} . \\
9.8 \mathrm{~g} . \\
2.6 \mathrm{~g} . \\
7.2 \mathrm{~g} . \\
8.2 \mathrm{~g} .\end{array}$ & $\begin{array}{l}\text { Abnormal } \\
\text { Abnormal } \\
\text { Normal }\end{array}$ & $\begin{array}{l}\text { II } \\
\text { I } \\
\text { I } \\
\text { I } \\
\text { II } \\
\text { I } \\
\text { I }\end{array}$ & 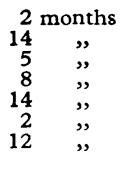 & $\begin{array}{l}\text { Remission } \\
\text { ”, } \\
\text { ”, } \\
\text { ", }\end{array}$ & $\begin{array}{l}\text { II } \\
\text { II } \\
\text { II } \\
\text { II } \\
\text { I } \\
\text { I } \\
\text { II }\end{array}$ & $\begin{array}{l}2.3 \mathrm{~g} . \\
4.6 \mathrm{~g} . \\
6.0 \mathrm{~g} . \\
4.8 \mathrm{~g} . \\
3.2 \mathrm{~g} . \\
4.4 \mathrm{~g} . \\
6.4 \mathrm{~g} .\end{array}$ & $\begin{array}{l}\text { Normal } \\
\text { ", } \\
\text { ", } \\
\text { ", } \\
\text { ", }\end{array}$ & $\begin{array}{l}\text { II } \\
\text { I } \\
\text { I } \\
\text { I } \\
\text { II } \\
\text { I } \\
\text { I }\end{array}$ \\
\hline \multicolumn{12}{|c|}{ Case Showing Improvement in Clinical State } \\
\hline 8 & Severe & II & $7 \cdot 6 \mathrm{~g}$ & & II & 14 months & Moderate & II & $2.6 \mathrm{~g}$ & Normal & I \\
\hline \multicolumn{12}{|c|}{ Cases Showing Clinical Deterioration } \\
\hline $\begin{array}{r}9 \\
10\end{array}$ & $\begin{array}{l}\text { Moderate } \\
\text { Mild }\end{array}$ & II & $2 \cdot 3 \mathrm{~g}$ & & I & 14 months & $\begin{array}{l}\text { Severe } \\
\text { Moderate }\end{array}$ & $\begin{array}{l}\text { III } \\
\text { III }\end{array}$ & $\begin{array}{l}8.0 \mathrm{~g} . \\
6.4 \mathrm{~g} .\end{array}$ & $\begin{array}{l}\text { Abnormal } \\
\text { Normal }\end{array}$ & II \\
\hline
\end{tabular}


colitis. But repeated observations of other subjects will be necessary to settle this crucial issue.

\section{Summary}

A pilot study previously reported (Salem et al., 1964) revealed that the small-intestinal mucosa often showed varying degrees of villous atrophy in patients with ulcerative colitis and that the faecal fat was likewise abnormally high in some patients. Similarly, the gastric mucosa sometimes showed superficial gastritis.

The study has now been extended to 60 patients with ulcerative colitis. In order to establish a yardstick of normality, a control group of 55 patients suffering from irritable-colon syndrome, psoriasis, or anaemia have also been studied.

Almost all the control subjects yielded small-intestinal biopsy specimens which were completely normal, while the others showed only minor villous abnormalities. By contrast, the incidence of villous abnormalities was high in ulcerative colitis and the degree of abnormality was often pronounced.

There was close connexion between the clinical state of activity of the ulcerative colitis and the condition of the smallintestinal biopsy specimen. When the ulcerative colitis was in remission small-intestinal abnormalities were minor in degree, whereas in severe attacks of ulcerative colitis the small-intestinal biopsy specimen frequently showed partial villous atrophy.

Similarly, the daily faecal fat excretion and a modified D-xylose test of small-intestinal absorption were often abnormal in actual attacks of ulcerative colitis. There is a good, though not perfect, correlation between these two tests of smallintestinal function and the small-intestinal biopsy appearances.

Electron-microscope studies on a sample of the smallintestinal biopsy specimens have shown normal epithelial cells with intact microvilli even in two specimens showing partial villous atrophy.

Histochemical observations on a small sample of the smallintestinal biopsy specimens suggest that certain enzymes may be deficient during an attack of ulcerative colitis.
Observations on small-intestinal motility have shown some differences between ulcerative colitis patients and control subjects.

Superficial gastritis is found in a minority of patients with ulcerative colitis. It shows a less pronounced correlation with the activity of the ulcerative colitis than do the villous abnormalities of the small intestine.

Repeat observations have been made on 10 patients with ulcerative colitis after a lapse of time varying from 2 to 14 months from their original examination. The small-intestinal mucosa almost always showed improvement when the patients were re-examined during complete remission of the ulcerative colitis. By contrast, two patients whose ulcerative colitis was more severe at the time of re-examination than originally showed increased villous abnormalities in the small intestine. The small-intestinal mucosa is therefore in a highly plastic state in ulcerative colitis and swings from normality to villous abnormality in parallel with the inflammatory changes in the colon.

\section{REFERENCES}

Caulfield, J. B. (1957). 7. biophys. biochem. Cytol., 3, 827.

Chaudhary, N. A., and Truelove, S. C. (1962). Quart. F. Med., 31, 307 Groisser, V. W., and Farrar, J. T. (1962). Amer f. dig. Dis., 7, 57.

Padykula, H. A., Strauss, E. W., Ladman, A. J., and Gardner, F. H. (1961). Gastroenterology, 40, 735.

Palade, G. E. (1952). f. exp. Med., 95, 285.

Poole, J., and Salem, S. N. (1965). Awaiting publication.

Ryan, T. J., Vickers, H. R., Salem, S. N., Callender, S. T., and Badenoch, J. (1964). Brit. F. Derm., 76, 555.

Salem, S. N., Salt, R. D., and Truelove, S. C. (1965). Gut. In press.

Truelove, S. C., and Richards, W. C. D. (1964). Brit. med. \%., $1,394$.

Sammons, H. G., Frazer, A. C., Gompertz, S. M., and Morgan, D. B. (1962). Malabsorption Syndrome. Symposium 2nd World Congress of Gastroenterology, Munich, 19 May.

Santini, R., jun., Sheehy, T. W., and Martinez-de-Jesus, J. (1961). Gastroenterology, 40, 772 .

Shearman, D. J. C., Girdwood, R. H., Wynn Williams, A., and Delamore, I. W. (1962). Gut, 3, 16

Shiner, M., and Birbeck, M. S. C. (1961). Ibid., 2, 277.

van der Kamer, J. H., Huinink, H. ten B., and Weyers, H. A. (1949). f. biol. Chem., 177,347 .
- An abridged version of a paper read at the annual conference of the Association of Probation Officers at Corpus Christi College, Cambridge, on 12 September 1964.

† Physician Deputy Superintendent, Horton Hospital, Epsom, Surrey; Gwilym Gibbon Fellow, Nuffield College, Oxford. received into prison for mental observation and reports to court who have been in a psychiatric hospital within twelve months of reception. The figures amount to an alarming total of 384 for 1963. They are often schizophrenics with some residual impairment, psychoneurotics, or psychopaths."

The numbers so remanded in England and Wales have increased from 6,366 in 1961 to 7,881 in 1963 , and the number of hospital orders made has risen correspondingly from 838 to 1,043. But these orders are made after prosecution. The main purpose of this paper is to draw attention to the unprosecuted offenders. There is evidence from personal inquiries from mental hospitals, including Horton, which admit this type of offender as emergencies from Metropolitan London that they too have increased in numbers. But as they do not appear in official criminal statistics they might therefore be omitted from any assessment of the size and nature of the overall problem of the mentally abnormal offender. 